\title{
Keefektifan Layanan Konseling Kelompok terhadap Kematangan Komunikasi Interpersonal Peserta Didik
}

\author{
Achmad Suhud, Siti Amega Isnaini \\ 1) Dosen Bimbingan dan Konseling FKIP UPS Tegal \\ 2) Mahasiswa Bimbingan dan Konseling FKIP UPS Tegal
}

Program Studi Bimbingan dan Konseling

FKIP - Universitas Pancasakti Tegal

\begin{abstract}
Abstrak
Tujuan penelitian ini adalah untuk mengetahui adanya keefektifan layanan konseling kelompok terhadap kematangan komunikasi interpersonal peserta didik. Pendekatan yang digunakan yaitu pendekatan kuantitatif. Jenis penelitiannya eksperimen. Desain penelitian pre-test and post-test. Populasi dalam penelitian ini adalah peserta didik kelas XI MA Salafiyah Karangtengah Warungpring Pemalang tahun pelajaran 2016/2017 sebanyak 144 peserta didik. Pengambilan sampel menggunakan sampling purposive diambil sebanyak 15 peserta didik. Metode pengumpulan data menggunakan angket, wawancara, observasi dan dokumentasi. Teknik analisis data menggunakan analisis statistik deskriptif presentase dan analisis statistik uji $\mathrm{t}(\mathrm{t}$-test). Hasil penelitian menunjukkan bahwa penghitungan pada pretest diperoleh skor rata-rata sebesar 93,8 dan pada post-test diperoleh skor rata-rata 130. Hasil simpulan ada keefektifan layanan konseling kelompok terhadap komunikasi interpersonal peserta didik di kelas XI MA Salafiyah Karangtengah Warungpring Pemalang.

Kata Kunci : Interpersonal, Konseling Kelompok, Komunikasi
\end{abstract}

\begin{abstract}
The purpose of this study is to investigate the effectiveness of group counseling services to learners' interpersonal communication maturity. The approach used is quantitative approach. The research type is experiment. Pre-test and post-test research design. The population in this study was the students of class XI MA Salafiyah Karangtengah Warungpring Pemalang 2016/2017 school year as many as 144 students. Sampling using purposive sampling taken as many as 15 students. Methods of data collection using questionnaires, interviews, observation and documentation. Data analysis technique using statistical analysis of descriptive percentage and test statistical analysis (t-test). The results showed that the pre-test calculation obtained an average score of 93.8 and While the post-test obtained an average score of 130. The result there is the effectiveness of group counseling services To the interpersonal communication of learners in class XI MA Salafiyah Karangtengah Warungpring Pemalang.
\end{abstract}

Key : Communication, Group Counseling, Interpersonal 


\section{PENDAHULUAN}

Dalam kehidupan sehari-hari manusia erat hubungannya dengan komunikasi, memerlukan orang lain untuk dapat memenuhi kebutuhannya. Tanpa terkecuali saat kita berada dalam dunia pendidikan. Peranan komunikasi sangatlah penting untuk mencapai sebuah tujuan pendidikan, yaitu sebagai media kegiatan belajar mengajar di kelas. Selain itu komunikasi sebagai sarana pemenuhan kebutuhan dalam perkembangan peserta didik dalam bidang pribadi, sosial, belajar, dan karir.

Pentingnya komunikasi mampu memenuhi kebutuhan fisik dan psikis. Istilah komunikasi diadopsi dari bahasa Inggris yaitu "communication", istilah ini berasal dari bahasa latin "communicare" yang berarti membagi sesuatu dengan orang lain, memberikan sebagian untuk seseorang, tukar-menukar, memberitahukan sesuatu kepada seseorang, bercakap-cakap, bertukar pikiran, berhubungan, berteman, dan lain sebagainya (Hardjana dalam Harapan, 2014:1).

Komunikasi bertujuan untuk mengirim pesan dari seseorang yang diterima orang lain atau sekelompok orang dengan efek umpan balik yang langsung. Dalam komunikasi terdapat istilah komunikasi dua arah, dimana dalam kegiatan komunikasi ini informasi yang disampaikan komunikator dapat berubah menjadi pemahaman yang baru karena peran komunikan itu sendiri yang mengartikan isi dari pesan yang disampaikan.

Salah satu komunikasi dua arah ini adalah efektivitas komunikasi interpersonal atau komunikasi antarpribadi yaitu komunikasi yang dilakukan dengan orang lain, dimana sering digunakan manusia saat berinteraksi dengan seseorang atau lingkungan masyarakat. Efektivitas komunikasi interpersonal sangat penting dalam kehidupan sehari-hari, terutama bagi peserta didik di sekolah. Komunikasi interpersonal juga dapat membantu perkembangan peserta didik dalam bidang sosial agar mampu memiliki hubungan yang baik dengan orang lain disekitarnya.

Peserta didik usia SMA/MA cenderung masuk dalam kategori usia remaja dimana pada rentan usia 12/13 tahun sampai 19/20 tahun. Pada usia ini menurut Yusuf dan Sugandhi (2011:12) biasanya ditandai dengan perubahan dalam aspek biologis, kognitif, dan sosioemosional yang nantinya untuk mempersiapkan masa dewasanya. Dalam usia ini individu berada pada posisi dimana lingkungan sosial sangat berperan dalam upaya membentuk sikap dan perilaku dari individu tersebut. Oleh karena itu efektivitas komunikasi interpersonal akan membantu individu berkembang ke arah yang positif.

Keefektifan komunikasi interpersonal yang baik dalam lingkungan sekolah adalah pada peserta didik yang berperan dalam membantu mengoptimalkan potensi dirinya, dan dapat digunakan sebagai sarana dalam membantu siswa mengatasi permasalahan yang muncul dan mengganggu kehidupan sehari-hari. Keefektifan komunikasi interpersonal yang terjalin dengan baik antar komponen sekolah dapat menciptakan hubungan yang hangat, dan nyaman dalam kesehariannya, serta dapat menciptakan keharmonisan antar masyarakat sekolah.

Berdasarkan studi empiris di lapangan banyak peserta didik yang mengalami masalah dalam komunikasi interpersonal. Hal ini didasarkan pada hasil observasi bahwa peserta didik belum bisa berhubungan dengan orang lain tanpa menilai, peserta didik masih mementingkan diri sendiri, belum memperlihatkan kepekaannya di lingkungan sekitar, belum dapat berempati kepada orang lain, serta belum bisa mengkomunikasikan keinginan kepada orang lain untuk bekerjasama mencari penyelesaian masalah yang sedang dihadapi. Dampak dari kegiatan komunikasi yang seperti disebutkan sebelumnya dalam hal ini merupakan suatu ciri bahwa lingkungan sosial tersebut mengalami tingkat komunikasi interpersonal yang rendah.

Dalam mengatasi setiap permasalahan yang dialami oleh peserta didik yang berkaitan dengan bidang pribadi, sosial, belajar, dan karier dan potensi yang ada dalam diri siswa, di sekolah terdapat layanan bimbingan dan konseling. Layanan konseling sendiri diartikan sebagai suatu proses intervensi yang bersifat membantu individu untuk meningkatkan pemahaman tentang diri sendiri dan hubungannya dengan orang lain (Wibowo, 2005:31). Sedangkan konseling kelompok merupakan cara yang amat baik untuk menangani konflik-konflik antar pribadi dan membantu individu dalam mengembangkan kemampuan pribadi mereka yang berorientasi pada pengembangan individu, pencegahan, dan pengentasan masalah (Hansen, Warner dan Smith.1984 dikutip oleh Wibowo, 2005:32). 
Fungsi utama dari pelaksanaan layanan konseling kelompok adalah pengembangan dan pengentasan. Sedangkan tujuan umum dari konseling kelompok adalah berkembangnya kemampuan sosialisasi peserta didik, khususnya komunikasi yang sering terganggu oleh perasaan, fikiran, wawasan, dan sikap yang tidak objektif serta tidak efektif. Adapun secara khusus tujuan dari layanan konseling kelompok adalah terselesaikannya masalah yang dialami peserta didik. Maka dari itu dalam layanan konseling kelompok setiap peserta didik yang menjadi anggota kelompok diberikan kesempatan berinteraksi antarpribadi. Interaksi sosial yang intensif dan dinamis selama pelaksanaan layanan, diharapkan tujuan layanan yang sesuai dengan kebutuhan individu anggota kelompok dapat tercapai secara maksimal. Pada kegiatan konseling kelompok setiap individu mendapatkan kesempatan untuk menggali tiap masalah yang dialami anggota. Kelompok juga dapat dipakai untuk belajar mengekspresikan perasaan, menunjukkan perhatian terhadap orang lain, dan berbagai pengalaman.

Menurut Imam (2014) penelitian dengan judul Keefektifan Layanan Konseling Kelompok dalam Meningkatkan Kemampuan Komunikasi Interpersonal Peserta Didik Kelas X SMA Lab School Pancasakti Kota Tegal Tahun Pelajaran 2013/2014. Adapun hasil dari perhitungan statistik uji $\mathrm{t}_{\text {hitung }}=$ 12.072, kemudian dikonsultasikan dengan nilai $\mathrm{t}_{\text {tabel }}=2,064$ yang diperoleh dari $\mathrm{df}=24$ taraf signifikan $5 \%$. Maka, $t_{\text {hitung }}>t_{\text {tabel }}$ yaitu $12.072>2,064$. Maka hipotesis alternatif (Ha) diterima sedangkan hipotesis nihil (Ho) ditolak.

Tujuan penelitian ini yaitu untuk mengetahui layanan konseling kelompok pada peserta didik kelas XI MA Salafiyah Karangtengah Warungpring Pemalang tahun pelajaran 2016/2017, mengetahui tingkat kematangan komunikasi interpersonal pada peserta didik kelas XI MA Salafiyah Karangtengah Warungpring Pemalang tahun pelajaran 2016/2017, mengetahui keefektifan layanan konseling kelompok terhadap kematangan komunikasi interpersonal peserta didik kelas XI MA Salafiyah Karangtengah Warungpring Pemalang tahun pelajaran 2016/2017.

\section{METODE}

Pendekatan dalam Penelitian ini menggunakan pendekatan kuantitatif, yaitu suatu pendekatan yang memungkinkan dilakukannya pencatatan data hasil penelitian secara nyata dalam bentuk data angka sehingga memudahkan proses analisis dan penafsirannya dengan menggunakan perhitungan-perhitungan statistik (analisis statistik). Pada penelitian ini peneliti menggunakan jenis penelitian eksperimen. Dalam penelitian eksperimen ada perlakuan (treatment), metode penelitian digunakan untuk mencari pengaruh perlakuan tertentu terhadap yang lain dalam kondisi yang terkendalikan (Sugiyono, 2015:107). Penelitian eksperimen menurut Suharsimi (2014:3) adalah suatu cara untuk mencari sebab akibat (hubungan kausal) antara dua faktor yang sengaja ditimbulkan oleh peneliti dengan mengurangi atau menyisihkan faktorfaktor lain yang bisa mengganggu. Desain pre test and post test group dalam desain ini observasi dilakukan sebanyak dua kali yaitu sebelum eksperimen dan sesudah eksperimen. Observasi yang dilakukan sebelum eksperimen disebut pre test, dan observasi sesudah eksperimen disebut post tes.

Dalam penelitian ini populasinya adalah peserta didik kelas XI MA Salafiyah Karangtengah Warungpring Pemalang tahun pelajaran 2016/2017 dengan jumlah 144 peserta didik. Dalam penelitian ini, peneliti mengambil jumlah keseluruhan populasi yang berjumlah 15 peserta didik yang memiliki kemampuan komunikasi interpersonal rendah untuk dijadikan sampel penelitian. Metode pengumpulan data dalam penelitian ini mengunakan angket, wawancara, observasi dan studi dokumen. Teknik analisis data dalam penelitian ini menggunakan analisis statistik deskriptif presentase dan analisis statistik uji $\mathrm{T}$.

\section{HASIL}

Try out dilaksanakan sebelum angket diberikan kepada sampel penelitian. Pelaksanaan try out ditujukan kepada responden lain yang bukan sampel yang kemudian dihitung validitas dan reliabilitasnya. Try out yang dilaksanakan peneliti yaitu di MA Nurul Huda Mereng Warungpring Pemalang pada tanggal 20 Mei 2017 dengan jumlah responden 30 peserta didik kelas XI jurusan IPA dan IPS. Angket diberikan kepada peserta didik untuk diisi sesuai dengan kondisinya, selain untuk menghitung validitas dan reliabilitas data, maksud dari dilakukannya try out ini yaitu untuk mengetahui tingkat kemampuan 
komunikasi interpersonal responden try out. Hal ini dikarenakan angket yang telah dibuat peneliti mencakup indikator-indikator yang digunakan untuk mengukur tingkat kemampuan komunikasi interpersonal peserta didik.

Penghitungan validitas angket komunikasi interpersonal terdiri dari 50 item dan dihitung menggunakan rumus korelasi Pearson Product Moment (PPM). Hasil penghitungan $\mathrm{r}_{\text {hitung }}$ kemudian dibandingkan $\mathrm{r}_{\text {tabel }}$ dengan jumlah responden trt out yaitu $\mathrm{N}=30$ dengan taraf signifikan $5 \%$ didapat $\mathrm{r}_{\text {tabel }}$ sebesar 0,361 . Setelah dibandingkan antara $\mathrm{r}_{\text {hitung }}$ dengan $\mathrm{r}_{\text {tabel }}$ maka akan diketahui item-item yang valid dan yang tidak valid.

Sebelum angket digunakan sebagai alat pengumpul data maka angket tersebut juga perlu diuji reliabilitasnya. Reliabilitas menujukkan keshahihan dari keseluruhan nomor item yang terdapat dalam sebuah angket. Pada penelitian ini uji reliabilitas menggunakan rumus spearman-brown. Dari hasil penghitungan, diperoleh nilai $\mathrm{r}_{11}$ sebesar 0,939 . Kemudian dikonsultasikan pada $\mathrm{r}_{\text {tabel }}$ dengan $\mathrm{N}=30$ dan taraf signifikan 5\% diperoleh nilai $\mathrm{r}_{\text {tabel }}$ sebesar 0,361. Karena $\mathrm{r}_{\text {hitung }}>\mathrm{r}_{\text {tabel }}$ yaitu 0,939 $>0,361$ maka angket dikatakan reliabel. Hasil penghitungan selengkapnya dilihat di lampiran.

Hasil presentase pretest akan disajikan dalam tabel dan grafik berikut:

Tabel 1

Persentase Pre-test

\begin{tabular}{c|c|c|c}
\hline Kelas & Frekuensi & Persentase & Kategori \\
\hline $77-85$ & 5 & $33 \%$ & Sangat rendah \\
\hline $86-94$ & 3 & $20 \%$ & Rendah \\
\hline $95-103$ & 5 & $33 \%$ & Cukup \\
\hline $104-112$ & - & - & Tinggi \\
\hline $113-122$ & 2 & $14 \%$ & Sangat Tinggi \\
\hline Jumlah & 15 & $100 \%$ & \\
\hline
\end{tabular}

Berdasarkan tabel diatas, dapat dilihat bahwa hasil pre-test pada 15 peserta didik yang termasuk dalam kategori sangat rendah sejumlah 5 peserta didik (33\%), kategori rendah sejumlah 3 peserta didik (20\%), kategori cukup sejumlah 5 peserta didik (33\%), kateggori tinggi tidak ada, dan kategori sangat tinggi sejumlah 2 peserta didik (14\%).

Adapun distribusi frekuensi hasil pre-test peneliti sajikan dalam bentuk diagram sebagai berikut :

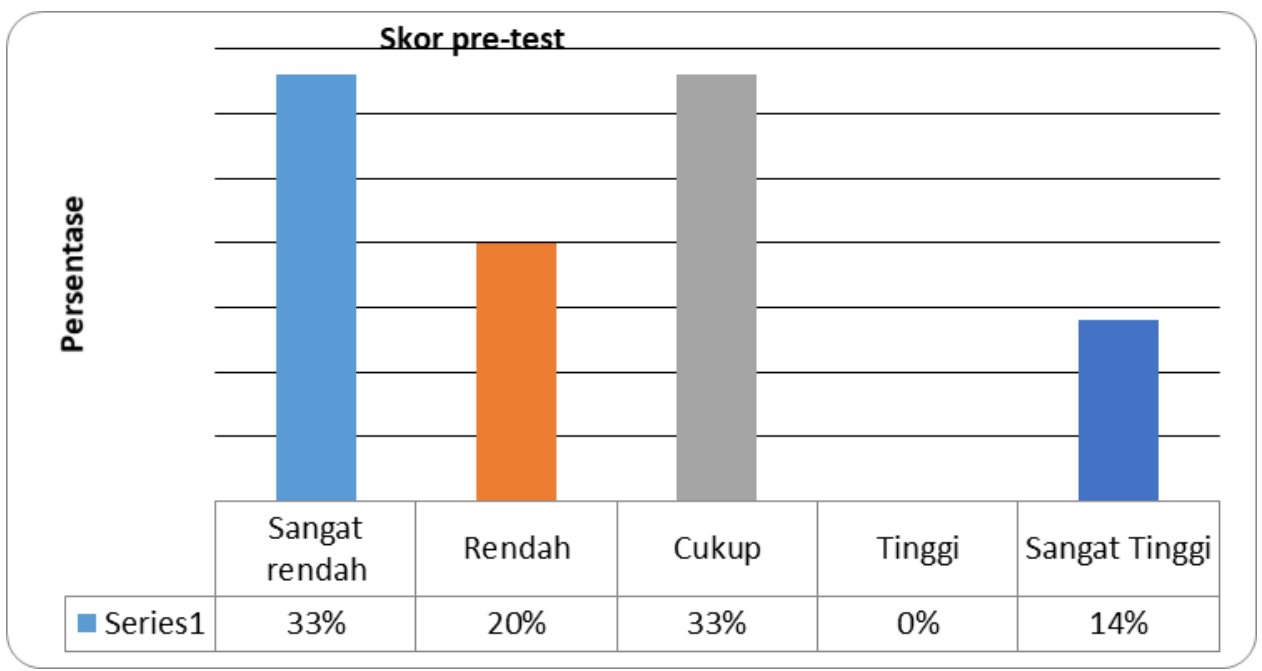

Gambar 1

Presentase Kriteria Komunikasi Interpesonal Pre-Tes 
Sedangkan hasil persentase pada post test akan disajikan pada tabel dan grafik berikut:

Tabel 4.2

Presentase Post-test

\begin{tabular}{l|l|l|l}
\hline \multicolumn{1}{c|}{ Kelas } & \multicolumn{1}{c|}{ Frekuensi } & \multicolumn{1}{c}{ Persentase } & \multicolumn{1}{c}{ Kategori } \\
\hline $113-119$ & 4 & $27 \%$ & Sangat rendah \\
\hline $120-126$ & 1 & $6 \%$ & Rendah \\
\hline $127-132$ & 3 & $20 \%$ & Cukup \\
\hline $133-140$ & 3 & $20 \%$ & Tinggi \\
\hline $141-147$ & 4 & $27 \%$ & Sangat Tinggi \\
\hline Jumlah & 15 & $100 \%$ & \\
\hline
\end{tabular}

Berdasarkan tabel diatas, dapat dilihat bahwa hasil post-test pada 15 peserta didik yang termasuk dalam kategori sangat rendah sejumlah 4 peserta didik (27\%), kategori rendah sejumlah 1 peserta didik (6\%), kategori cukup sejumlah 3 peserta didik (20\%), kateggori tinggi sejumlah 3 peserta didik (20\%), dan kategori sangat tinggi sejumlah 4 peserta didik (27\%).

Adapun distribusi frekuensi hasil post-test peneliti sajikan dalam bentuk diagram sebagai berikut:



Gambar 2

Presentase Kriteria Komunikasi Interpersonal Post-test

Berdasarkan hasil analisis tingkat kemampuan komunikasi interpersonal peserta didik sebelum mendapatkan perlakuan (pre-test) dan sesudah mendapatkan perlakuan (post-test) yang telah dijelaskan di 
atas, maka dapat dilihat perbedaan dengan membandingkan antara jumlah rata-rata pada pre-test yaitu 94 dan hasil rata-rata pada post-test dengan jumlah 130 atau dengan membandingkan jumlah skor total pada pre-test sebesar 1407 dan jumlah skor total pada post-test sebesar 1952.

\section{PEMBAHASAN}

Setelah diberi perlakuan (treatment) berupa konseling kelompok selama lima kali pertemuan, maka terjadi peningkatan kkomunikasi interpersonal pada peserta didik kelas XI MA Salafiyah Karangtengah Warungpring Pemalang. Sebelum perlakuan (pre-test) skor rata-ratanya 94 dan setelah perlakuan (posttest) meningkat menjadi 130 . Hal ini juga dapat dilihat dari perbandingan jumlah skor total pada pre-test yaitu 1407 dan jumlah skor total post-test yaitu 1952, terdapat peningkatan skor sebesar 545. Dari hasil pre-test dan post-test dapat diketahui nilai $\mathrm{t}_{\text {hitung }} 6,914$, jika koefesien $\mathrm{t}_{\text {hitung }}$ sebesar 6,914 dikonsultasikan pada $\mathrm{t}_{\text {tabel }}=2,145$ yang diperoleh dari $\mathrm{df}=15-1=14$ pada taraf signifikan $5 \%$ maka diperoleh $\mathrm{t}_{\text {hitung }}>$ $t_{\text {tabel }}$ yaitu 6,914 $>2,145$, maka hipotesis alternatif $(\mathrm{Ha})$ yang berbunyi "Adanya Keefektifan Layanan Konseling Kelompok Terhadap Kematangan Komunikasi Interpersonal pada Peserta Didik Kelas XI MA Salafiyah Karangtengah Warungpring Pemalang Tahun Pelajaran 2016/2017” diterima.

\section{SIMPULAN}

Keefektifan layanan konseling kelompok terhadap kematangan komunikasi interpersonal pada peserta didik kelas XI MA Salafiyah Karangtengah Warungpring Pemalang tahun pelajaran 2016/2017, maka dapat disimpulkan sebagai berikut: 1) Tingkat kemampuan komunikasi interpersonal peserta didik dari data pre-test menunjukkan bahwa 15 peserta didik yang termasuk dalam kategori sangat rendah pada interval 77-85 sejumlah 5 peserta didik (33\%), kategori rendah pada interval 86-94 sejumlah 3 peserta didik (20\%), kategori cukup pada interval 95-103 sejumlah 5 peserta didik (33\%), kateggori tinggi pada interval 104-112 tidak ada, dan kategori sangat tinggi pada interval 113-122 sejumlah 2 peserta didik (14\%). Dengan jumlah skor total pre-test 1407 dan rata-rata perolehan pre-test sebesar 94, 2) Tingkat kemampuan komunikasi interpersonal peserta didik dari data post-test menunjukkan bahwa 15 peserta didik yang termasuk dalam kategori sangat rendah pada interval 113-119 sejumlah 4 peserta didik (27\%), kategori rendah pada interval 120-126 sejumlah 1 peserta didik (6\%), kategori cukup pada interval 127-132 sejumlah 3 peserta didik (20\%), kateggori tinggi pada interval 133-140 sejumlah 3 peserta didik (20\%), dan kategori sangat tinggi pada interval 141-147 sejumlah 4 peserta didik (27\%). Dengan jumlah skor total post-test 1952 dan rata-rata perolehan post-test sebesar 130,3) Dari hasil penghitungan uji t diketahui bahwa t.hitung 6,914, jika koefesien $t_{\text {hitung }}$ sebesar 6,914 dikonsultasikan pada $t_{\text {tabel }}=2,145$ yang diperoleh dari $\mathrm{df}=15-1=14$ pada taraf signifikan 5\% maka diperoleh $t_{\text {hitung }}>\mathrm{t}_{\text {tabel }}$ yaitu 6,914 $>2,145$, maka hipotesis alternatif $(\mathrm{Ha})$ yang berbunyi "Adanya Keefektifan Layanan Konseling Kelompok Terhadap Kematangan Komunikasi Interpersonal pada Peserta Didik Kelas XI MA Salafiyah Karangtengah Warungpring Pemalang Tahun Pelajaran 2016/2017" diterima dan hipotesis nihil (Ho) ditolak.

\section{SARAN}

Saran-saran yang dapat peneliti sampaikan sebagai bahan memajukan sekolah adalah sebagai berikut: 1) Kepala Sekolah, memberikan kontribusi kepada kepala sekolah dalam pengambilan kebijakan berbagai layanan bimbingan dan konseling baik di bidang pribadi, sosial, belajar maupun karier agar pemberiannya dimaksimalkan, 2) Dewan Guru, Guru khususnya guru Bimbingan dan Konseling mampu memberikan layanan berupa layanan individu maupun kelompok diseluruh bidang bimbingan dengan maksimal dan mampu mengaplikasikan berbagai layanan bimbingan dan konseling khususnya konseling kelompok dalam setiap penanganan berbagai permasalahan. Serta untuk meningkatkan kemampuan komunikasi interpersonal peserta didik, 3) Peserta didik, Disarankan peserta didik dalam rangka perwujudan pengembangan diri di sekolah terutama dalam peningkatan kemampuan komunikasi interpersonal atau komunikasi antarpribadi dapat ditangani dengan tepat dan benar oleh guru Bimbingan dan Konseling. 


\section{DAFTAR PUSTAKA}

Arikunto, Suharsimi. 2014. Prosedur Penelitian; Suatu Pendekatan Praktik. Jakarta: Rineka Cipta.

Harapan, Edi dan Syarwani Ahmad. 2014. Komunikasi Antarpribadi; Perilaku Insani Dalam Organisasi Pendidikan. Jakarta: Rajawali Pers.

Nasirudin, Imam. 2014. "Keefektifan Layanan Konseling Kelompok dalam Meningkatkan Kemampuan Komunikasi Interpersonal Peserta Didik kelas X SMA Lab School Pancasakti Kota Tegal Tahun Pelajaran 2013/2014. Skripsi Universitas Pancasakti Tegal.

Sugiyono. 2015. Metode Penelitian Pendidikan; Pendekatan Kuantitatif, Kualitatif, dan R\&D. Bandung: Alfabeta.

Yusuf, Syamsu dan Nani M. Sugandhi. 2011. Perkembangan Peserta Didik. Jakarta: Rajawali Pers.

Wibowo, Mungin Eddy. 2005. Konseling Kelompok Perkembangan. Semarang: UNNES Press. 